Article

\title{
Effect of pH on Rheological and Filtration Properties of Water-Based Drilling Fluid Based on Bentonite
}

\author{
Hany Gamal@, Salaheldin Elkatatny *(1), Salem Basfar® and Abdulaziz Al-Majed \\ Petroleum Department, King Fahd University of Petroleum \& Minerals Box 5049, Dhahran 31261, Saudi Arabia; \\ g201706870@kfupm.edu.sa (H.G.); g201407960@kfupm.edu.sa (S.B.); aamajed@kfupm.edu.sa (A.A.-M.) \\ * Correspondence: elkatatny@kfupm.edu.sa; Tel.: +966-594663692
}

Received: 5 November 2019; Accepted: 25 November 2019; Published: 27 November 2019

\begin{abstract}
The design of drilling fluids is very important for the drilling operation success. The rheological properties play a key role in the performance of the drilling fluid. Therefore, studying the mud rheological properties of the water-based drilling fluid based on bentonite is essential. The main objectives of this study are to address the effect of $\mathrm{pH}$ changes on the rheological and filtration properties of the water-based drilling fluid based on bentonite and to provide a recommended $\mathrm{pH}$ range for this drilling fluid for a safe and high-performance drilling operation. Different samples of the water-based drilling fluid based on bentonite with different $\mathrm{pH}$ values were prepared, and the rheological properties such as plastic viscosity, yield point, and gel strength were measured. After that, the filtration test was performed under 300 psi differential pressure and $200{ }^{\circ} \mathrm{F}$. The $\mathrm{pH}$ for the water-based drilling fluid based on bentonite significantly affects the mud rheology. The shear stress and shear rate relation were varying with the change in the $\mathrm{pH}$. Increasing the $\mathrm{pH}$ from 8 to 12 resulted in decreasing the plastic viscosity by $53 \%$ and the yield point by $82 \%$, respectively. The ratio of yield point / plastic viscosity was 1.4 for $\mathrm{pH}$ of 8 while it decreased to 0.5 for a $\mathrm{pH}$ of 11 and 12. There was a significant decrease in the gel strength readings by increasing the $\mathrm{pH}$. The filtrate volume and filter cake thickness increased by increasing $\mathrm{pH}$. The filtration volume increased from $9.5 \mathrm{~cm}^{3}$ to $12.6 \mathrm{~cm}^{3}$ by increasing the $\mathrm{pH}$ from 9 to 12 . The filter cake thickness was $2 \mathrm{~mm}$ at $9 \mathrm{pH}$, while it was increased to $3.6 \mathrm{~mm}$ for $12 \mathrm{pH}$. It is recommended from the results to keep the $\mathrm{pH}$ of water-based drilling fluid based on bentonite in the range of 9 to 10 as it provides the optimum mud rheological and filtration properties. The findings of this study illustrated that keeping the $\mathrm{pH}$ in the range of 9 to 10 will reduce the plastic viscosity that will help in increasing the rate of penetration and reducing the required pump pressure to circulate the mud to the surface which will help to sustain the drilling operation. In addition, reducing the filtrate volume will produce a thin filter cake which will help in avoiding the pipe sticking and protect the environment. In general, optimizing the $\mathrm{pH}$ of the water-based drilling fluid based on bentonite in the range of 9 to 10 will improve the drilling operation and minimize the total cost.
\end{abstract}

Keywords: bentonite mud; water-based drilling fluid; rheological properties; filtration properties; $\mathrm{pH}$ effect

\section{Introduction}

The drilling fluids are critical in the oil and gas drilling operations. To reach the target formations in the well, the drilling fluid program should be designed carefully to safely drill the well with economical wise. Drilling fluids cost is considered to share a portion of around $25-40 \%$ of the total drilling operations cost [1]. Some problems that occur during the drilling operations such as mud losses will add more cost to the total drilling cost. Several factors affect the ratio of the drilling fluid cost to the total drilling cost, such as well location, drilled formation type, and other technical problems 
that might be encountered during the drilling operations [2,3]. The drilling fluids can be classified according to their base such as water-based, oil-based, gas-based, or synthetic-based, and all types are used in variable situations and with different additives [4]. Among these types, the water-based mud is the most commonly used drilling fluid [5]. The drilling mud is designed based on several factors and it should primarily be designed to control the formation pressure and to be environmentally friendly [4]. The mud design must consider the formation temperature, losses zones, and shale induced problems. The drilling fluids should provide the essential functions, including carrying cuttings out of the hole [hole cleaning], cooling and lubricating the drill string, providing wellbore stability, and should avoid damaging the formation. Moreover, the drilling fluids transfer the hydraulic power from the surface to downhole motors.

\subsection{Bentonite in Drilling Fluids}

Bentonite is a montmorillonite clay which is used with the drilling fluids to provide the required rheology [6-9]. Bentonite mainly used with water-based mud (WBM) to provide significant functions such as increasing the viscosity and filtration control [10]. Bentonite interacts chemically with the water and swells as it absorbs the water as a result. Bentonite as clays are naturally absorbent, and when the bentonite is exposed to water, bentonite attracts the positively charged surfaces in water to its negative face by electrostatic attraction forces [11]. This phenomenon enables the bentonite to absorb seven to 10 times its weight and swell up to 18 times its original volume [12]. Bentonite reacts chemically with several organic materials and forms compounds that are mainly used as gelling agents [13]. The mud gel strength is important for carrying the drilled cuttings in case no mud circulated.

Sodium bentonite is used in the drilling mud, is highly dispersive, and has a high swelling capability. Calcium bentonite is another type of bentonite, but it is not appropriate to be used as drilling fluid additive since it has the small swelling capability and it affects the mud rheology badly [10].

The raw bentonite is extracted and processed through many purification operations to be properly used with the drilling fluids. Mechanical and chemical processes are conducted for the raw bentonite such as sieving or adding chemicals to separate the pure bentonite from the impurities. The good quality of bentonite affects the mud rheological properties as it provides the essential viscosity and filtration loss [14-16].

\subsection{Effect of Bentonite on Mud Rheology}

Mud rheology is a very important property for the drilling fluids, which should be stable under various conditions while drilling to avoid any problems in the drilling operations. Mud rheological properties in terms of plastic viscosity, gel strength, etc. are tested frequently while drilling. Such properties are measured on a continuous basis during the drilling operations and should be adjusted by adding additives or dilution to meet the mud program design. Bentonite is one of the mud additives and its concentration should be evaluated as it affects the mud rheological properties [17]. The downhole pressure and temperature conditions affect the mud rheological properties. Therefore, flat-rheology fluid is designed to overcome the high-pressure, high-temperature HPHT drilling conditions. The rheology modifiers additives should provide a good profile for the HPHT applications [18].

Recently, research trends are directed to produce low solid content drilling fluids which require replacing some amount of bentonite by another nanoparticle for the drilling mud composition $[19,20]$. That low solid content fluid has several advantages, such as increasing the drilling rate of penetration, forming a thin filter cake layer, decreasing the friction losses, shale inhibition, and improving the rheological and filtration properties [21]. However, one of the main disadvantages of the low solid drilling fluid is the low carrying capacity of the drilled cuttings by the drilling mud [11]. Therefore, many kinds of research have been performed to improve the mud carrying capacity for the drilled cuttings by using additives to modify the mud rheological properties. Such additives include graphene oxide [22] and $\mathrm{CuO}$ and $\mathrm{ZnO}$ [23]. In addition, another work was conducted to modify the mud rheology 
using synthetic polymers such as terpolymer [24], amphoteric polymer [25], and copolymer [26]. The nanotechnology was also applied for the mud rheology modification [27-30].

Song et al. [8,9] studied the effect of using a small amount of cellulose nanoparticles to replace bentonite amount to modify the drilling fluid rheology. The study showed that the new formulation modified the mud rheological properties. The use of the cellulose nanoparticles formed a more negatively-charged surface on bentonite particles, increased the solution stability, and provided low fluid viscosity [31].

Ahmad et al. [19] studied the bentonite-polymer dispersions effect on the mud rheology and filtration properties. The study showed that bentonite-polymer dispersions greatly improved the rheological properties of the drilling fluid which indicates the ability of the bentonite-polymer to enhance the drilling fluid performance.

Li et al. [11] studied adding the chitin nanocrystals that are isolated from speckled swimming crab shell waste to the bentonite water-based mud as a rheology modifier. The results showed an improvement in the mud rheological and filtration properties. Saboori et al. [20] incorporated copper oxide/polyacrylamide nanocomposite into the bentonite water-based mud. The nanocomposite additive found to be more effective for filtration and mud rheology when it is added to water-based mud. The high-temperature affects the bentonite particles dispersions. The bottom hole high temperatures lead to bentonite aggregation, which could be prevented by adding several additives such as synthetic polymers, polysaccharides, cellulose, or starch as thinners [32].

Kanna et al. [33] studied the effect of bentonite and other mud additives on the mud optimum design in terms of mud rheology, $\mathrm{pH}$ value, and filtration properties. Huang et al. [34] showed that API Bentonite slurries displayed unusual rheology at low $\mathrm{pH}$. The drilling fluid yield stress and viscosity had low values at low $\mathrm{pH}$, and maximum yield stress and viscosity was found to be at $\mathrm{pH}$ 9. Akinade et al. [35] showed that the bentonite clay needed further improvements to be used in the drilling fluids to provide an optimum mud rheological and filtration properties as API standards. Kuma et al. [36] provided a study for the bentonite-based mud for properties improvement. The study tested adding carboxymethyl cellulose, sodium salt, partially hydrolyzed polyacrylamide (PHPA) polymer, and polyacrylamide, and the results showed an improvement in the mud rheological and filtration properties.

In addition, different polymers have been used in other filed applications such as polymer flooding for heavy oil reservoirs to increase the oil recovery $[37,38]$. The polymer flooding showed an economic profit performance than the steam-assisted gravity drainage system for heavy oil reservoirs [39].

\subsection{Effect of Bentonite-Based Mud on Drilling Performance}

From actual field data, it was found that bentonite-based mud had a bad effect on the penetration rate performance, and so it was recommended to reduce the bentonite amount as much as possible or to use another alternative than bentonite [40]. In the study, all the other factors that can affect the ROP as the hole size, weight on bit (WOB), rotation speed (RPM), bit type, drilled formation, bit hydraulics, and the mud type are similar to eliminate their effect. The study results showed that there is a direct relation between ROP and the mud viscosity, as ROP increased by $58 \%$ for adjusted mud rheological properties.

It is common in the Middle East to drill the surface hole sections with a spud mud composed of pre-hydrated bentonite. The shallow formations are soft and it is supposed to have losses during mud circulation. From practical, it is recommended to add thinner for the mud formula in case of the bentonite content $35-50 \mathrm{lb} / \mathrm{bbl}$ to control the mud viscosity. Due to the environmental constraints, using the inverted emulsion muds to drill the surface sections is not allowed. Bentonite-based spud mud is considered as an alternative to drill the surface sections. However, it is reported in the daily drilling data that the ROP decrease when using the bentonite-based mud when compared with emulsion mud, as shown in Figure 1. The real field drilling data showed that using emulsion mud system showed better ROP performance than using the high bentonite mud systems. 


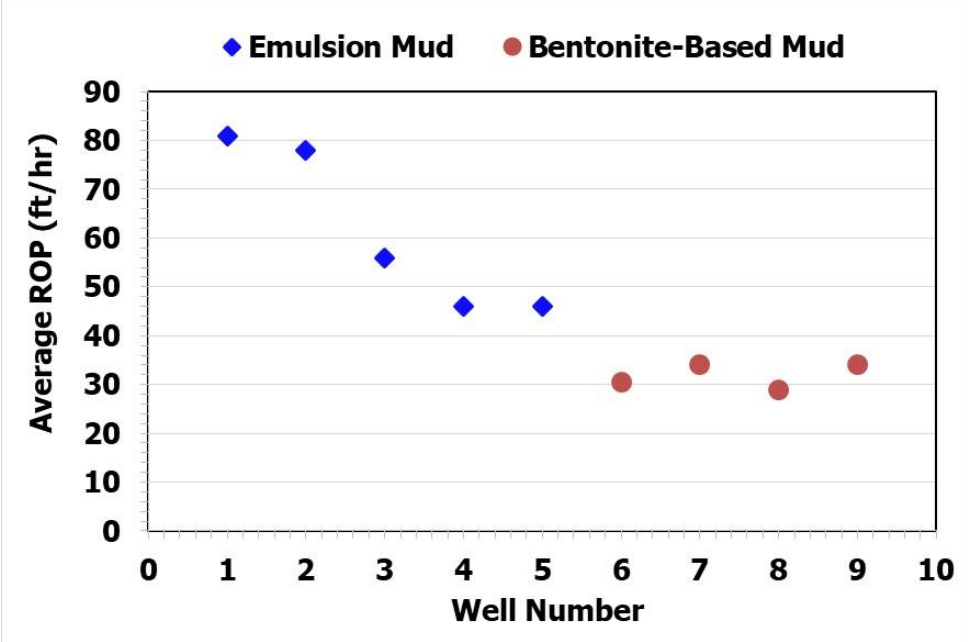

Figure 1. Drilling ROP comparison between bentonite-based and emulsion muds (Field Data).

From the literature review, it is clear that bentonite affects the mud rheological and filtration properties, and the mud rheology design is critical for the drilling operation. In addition, the bentonite-based mud rheology affects the ROP, so it will have an impact on the well drilling cost. The work that has been discussed above mostly studied the additives used for the bentonite-based mud rheology modifier. Li et al. [11] focused on the $\mathrm{pH}$ effect for the bentonite water-based mud containing chitin nanocrystals as a mud modifier. They showed that the improvement in the mud rheology was found when the $\mathrm{pH}$ changed from neutral to acidic, and that might cause tubular corrosion. The previous discussion indicates that the effect of $\mathrm{pH}$ control on the bentonite water-based mud did not study very well in the literature.

In this study, the effect of changing the $\mathrm{pH}$ of water-based mud based on bentonite on the mud rheology and filtration properties will be extensively studied. Figure 2 illustrates a sketch that shows the change in the mud properties with the change of the $\mathrm{pH}$ vale. A recommendation of the optimum range for $\mathrm{pH}$ for this fluid type will be provided based on the obtained results. Sustain the rheological properties of the drilling fluid while drilling is very important which will help the driller to drill the hole faster and reduce the total cost of the drilling operation. In addition, optimizing the rheological properties will minimize or eliminate the fluid loss to any water bearing formation to protect the environment.

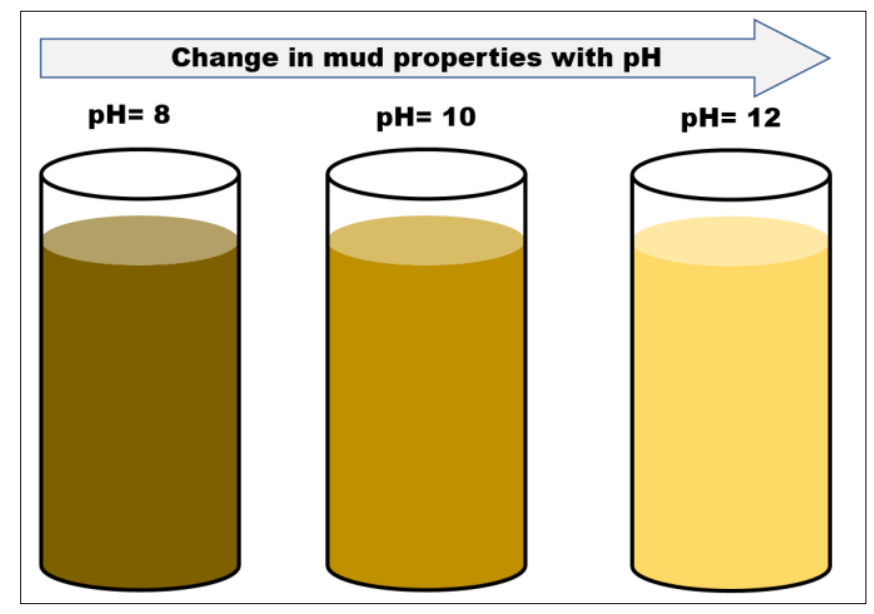

Figure 2. Change in the mud properties with changing the $\mathrm{pH}$. 
The used materials and the experimental procedure will be explained in Section 2. Results and discussion will be explained in details in Section 3. Finally, the summary and the conclusion will be explained in Section 4.

\section{Materials and Experimental Procedure}

\subsection{Materials}

The water-based drilling fluid based on bentonite (WBDFBOB) was mixed. Table 1 shows the composition of the WBDFBOB used in this study. The mud composed of water that represents the base fluid, bentonite as viscosifier, caustic soda to control the water activity, lignosulphonate for bentonite de-flocculation [41], and starch was used for fluid losses control. The formula used represents the base case for the study and other scenarios of changing only the $\mathrm{pH}$ for the formula were performed. Changing the $\mathrm{pH}$ was performed by increasing the amount of sodium hydroxide $[\mathrm{NaOH}]$ of the mud to reach the desired $\mathrm{pH}$ value.

Table 1. Composition of HBWBDF.

\begin{tabular}{ccc}
\hline Item & Amount, $\mathbf{g}$ & Function \\
\hline Water & 340 & Base fluid \\
\hline Bentonite & 40 & Viscosifier \\
\hline Caustic Soda & 0.5 & Water Activity \\
\hline Lignosulphonate & 3 & Dispersant \\
\hline Starch & 3 & Fluid loss control \\
\hline
\end{tabular}

\subsection{Experimental Program}

The water-based drilling fluid based on bentonite mud formulation in Table 1 was used to prepare the mud samples as follows:

1. Different samples of bentonite-based mud were mixed for different $\mathrm{pH}$ values [8-12].

2. Density was measured at ambient conditions for each sample.

3. Measurements for the rheological properties such as plastic viscosity (PV), yield point (YP), and gel strength [10-seconds, 10-minutes, 30-minutes readings] were obtained using the mud rheometer at a temperature of $120^{\circ} \mathrm{F}$ and atmospheric pressure.

4. Filtration test was performed. The test was performed using the high-pressure, high-temperature filter cell under 300 psi differential pressure and $200^{\circ} \mathrm{F}$, and using a 25-micron ceramic disk. The test extended for 40 minutes until no flow out.

5. The filtrated volume and filter cake thickness was measured for each mud sample.

The drilling fluid $\mathrm{pH}$ was measured using the $\mathrm{pH}$ meter with an accuracy of \pm 0.05 while the mud density was measured using the mud balance with an accuracy of \pm 0.1 . The rheological properties were obtained using the Fan VG 35 with an accuracy of \pm 0.5 .

\section{Results and Discussion}

\subsection{Mud Density}

After mixing and preparing the bentonite-based mud with different $\mathrm{pH}$ values, the mud density was measured at ambient conditions. Figure 3 shows that there was no change in the fluid density as it remained constant at $8.8 \mathrm{ppg}$ as the $\mathrm{pH}$ increased from 9 to 12 . 


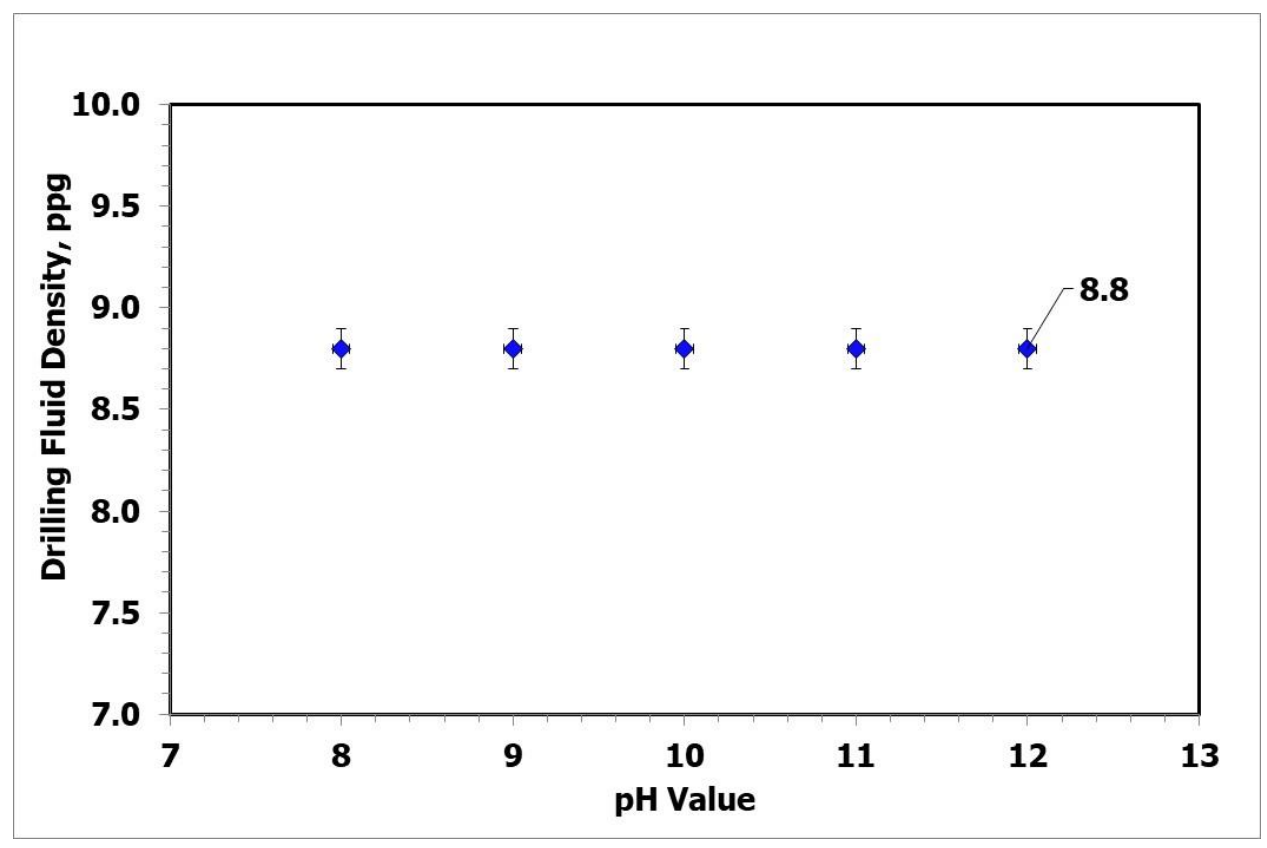

Figure 3. Density of bentonite-based mud at ambient condition for different $\mathrm{pH}$.

\subsection{Shear-Stress Shear-Rate Behavior}

The shear-stress shear-rate behavior of the WBDFBOB for different $\mathrm{pH}$ at $120^{\circ} \mathrm{F}$ was performed. The results, as shown in Figure 4, showed that increasing the $\mathrm{pH}$ for the samples resulted in decreasing the plastic viscosity, and Figure 4 indicated that from the shear-stress shear-rate curves. The curves show a similar increasing profile for the shear-stress shear-rate for all scenarios. The effect of $\mathrm{pH}$ on the mud rheological properties supposed to be because of a result of the change in the nanostructured of bentonite surfaces [11].

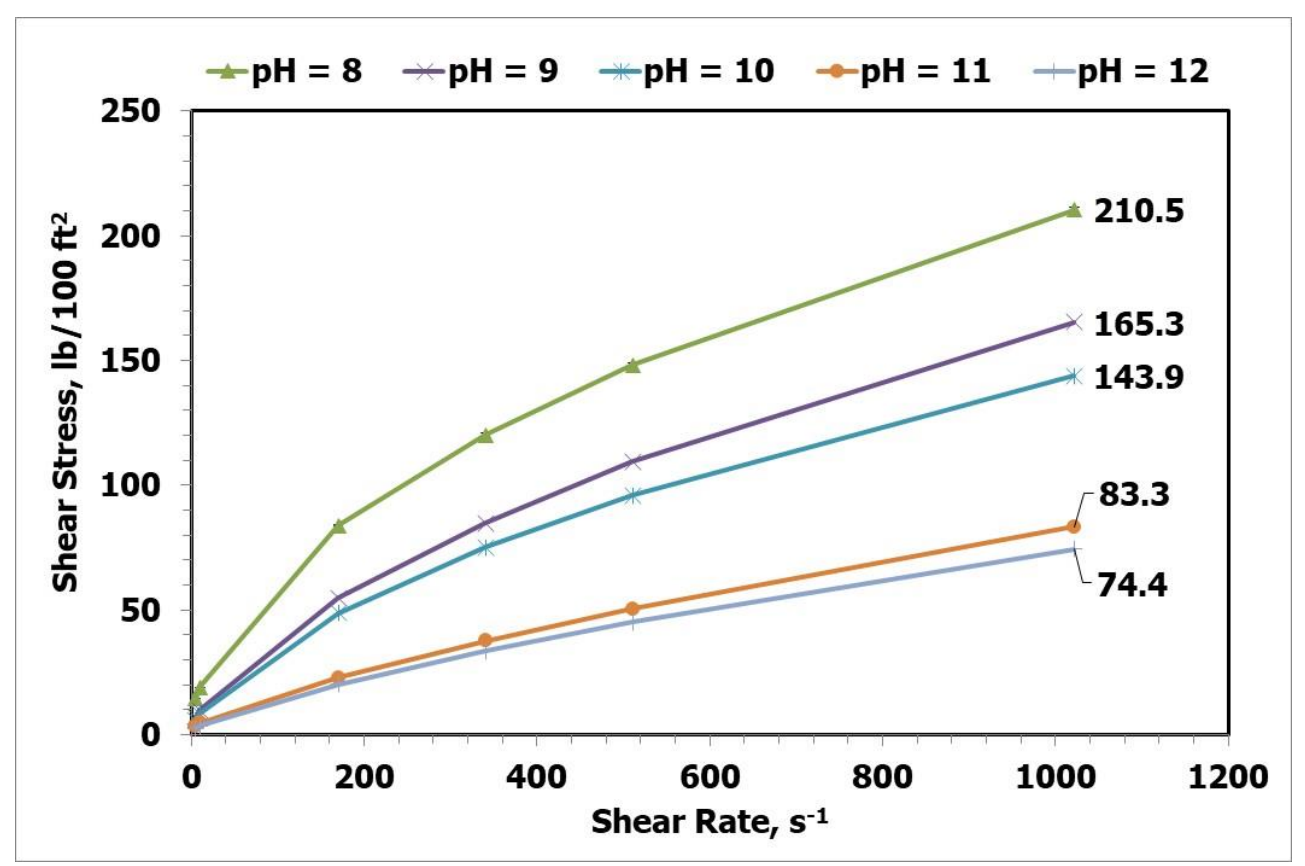

Figure 4. Shear-stress shear-rate behavior of WBDFBOB at $120^{\circ} \mathrm{F}$ for different $\mathrm{pH}$ scenarios. 


\subsection{Rheological Properties}

The values of the yield point (YP) represent a key control role in the efficiency of hole cleaning. Drilling mud with a greater value of YP is desired for the hole cleaning operations as it has a high level of carrying capacity for the mud solid particles and the drilled cuttings [35]. The plastic viscosity and $\mathrm{YP}$ for the bentonite-based WBM were measured over the $\mathrm{pH}$ range for this study. Figure 5 shows the changes in the plastic viscosity and YP for different the mud samples of WBDFBOB with different $\mathrm{pH}$ values. It is clear that increasing the $\mathrm{pH}$ from 8 to 12 resulted in decreasing the plastic viscosity from 62.4 to $29.3 \mathrm{cP}$, and also decreasing the $\mathrm{YP}$ from 85.7 to $15.8 \mathrm{lb} / 100 \mathrm{ft}^{2}$. Increasing the $\mathrm{pH}$ from 8 to 12 resulted in decreeing the PV by $53 \%$ and the YP also decreased significantly by $82 \%$.

Applying the Herschel-Bulkley flow model to determine the low-shear yield point (LSYP) [42], Equation (1).

$$
\mathrm{LSYP}=3 \mathrm{R}_{3}-\mathrm{R}_{6}
$$

where $R_{3}$ is the rheometer reading at $3 \mathrm{rpm}$ and $R_{6}$ is the rheometer reading at $6 \mathrm{rpm}$.

It is clear for Figure 5 that the value of LSYP was dramatically decreased by increasing the $\mathrm{pH}$, where the LSYP was decreased from $80 \mathrm{lb} / 100 \mathrm{ft}^{2}$ to $1.4 \mathrm{lb} / 100 \mathrm{ft}^{2}$ as the $\mathrm{pH}$ increased from 8 to 12 .

The obtained results confirmed the significant effect of the $\mathrm{pH}$ on the mud rheological and filtration properties. The reason for that is the change in mud rheology revealed that the nanostructure changes for the plates and particle surfaces of the drilling fluid based on the new value of the $\mathrm{pH}$. In addition, the increase of $\mathrm{pH}$ values will prevent the dispersion of the bentonite particles, and as a result, the particles will not help in building the fluid viscosity. Furthermore, that will reduce the ability of the fluid to carry the drilled cuttings and that is appeared clearly by the lower YP values at higher $\mathrm{pH}$.

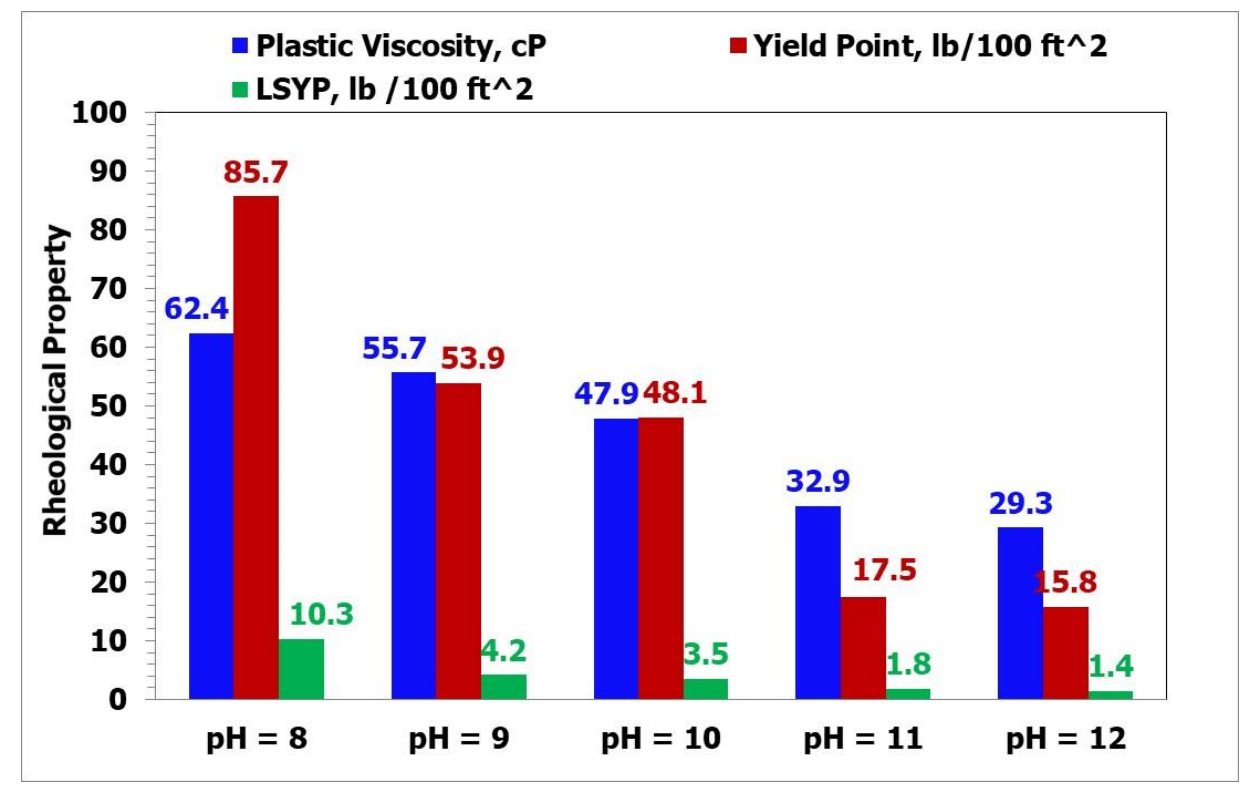

Figure 5. Change of $\mathrm{PV}, \mathrm{YP}$, and LSYP of WBDFBOB for different $\mathrm{pH}$ scenarios at $120^{\circ} \mathrm{F}$.

The yield point to plastic viscosity YP/PV ratio for the mud is very important, as it is an indicator of the drilling operation conditions [1]. Turbulent flow is preferable in high-angle wells for hole cleaning. However, to ensure a mud gel strength is less important, as the carrying capacity does not affect by the mud rheology. In case turbulent flow cannot be maintained, the YP/PV ratio should be kept as high as possible. Also, if the hole gauging cannot be maintained and the borehole diameter enlarges, then a high $\mathrm{YP} / \mathrm{PV}$ ratio is appropriate for the mud system. In laminar flow, the carrying capacity is affected by mud rheological properties. Therefore, when YP to plastic viscosity [YP/ PV] increases, the carrying capacity of the mud increases [1]. 
Figure 6 shows the changes in the $\mathrm{YP} / \mathrm{PV}$ ratio over a wide range of $\mathrm{pH}$ for the bentonite-based mud. The highest value of $\mathrm{YP} / \mathrm{PV}$ is 1.4 for $\mathrm{pH}$ of 8 and the ratio was 1.0 for $\mathrm{pH}$ values of $[9,10]$ and it decreased to 0.5 for $\mathrm{pH}$ of 11 and 12. The results for $\mathrm{YP} / \mathrm{PV}$ ratios show that for increasing $\mathrm{pH}$ values, there is a decreasing in the ratio of $\mathrm{YP} / \mathrm{PV}$ by $64 \%$.

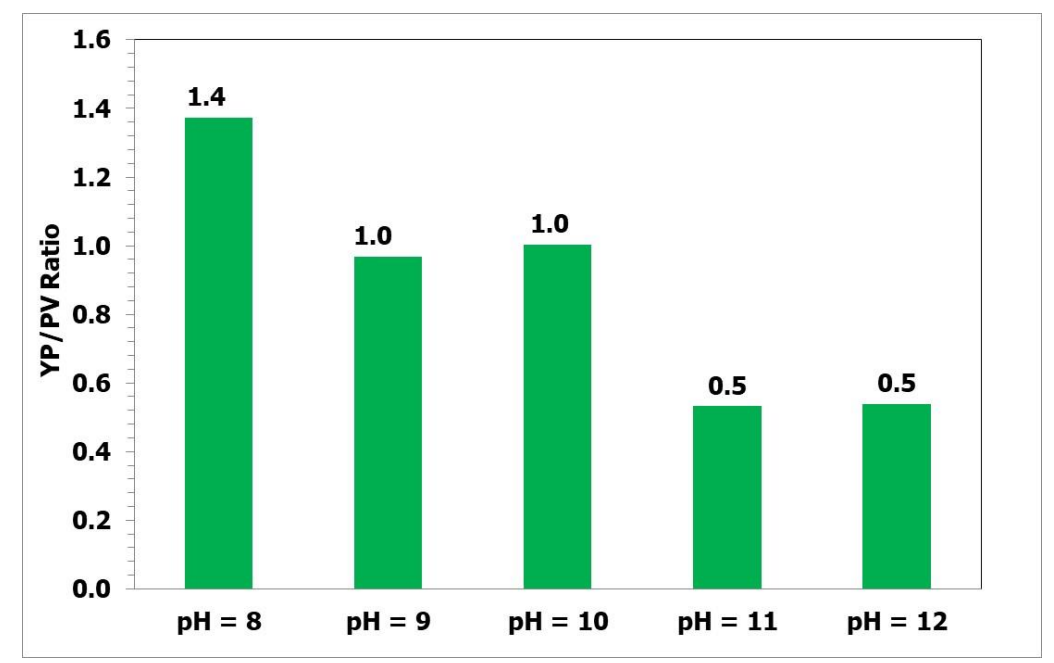

Figure 6. Change of $\mathrm{YP} / \mathrm{PV}$ ratio of $\mathrm{WBDFBOB}$ for different $\mathrm{pH}$.

The gel strength of drilling fluid represents the capability of the mud to keep the drilled cuttings in suspension in case of the circulation stopped [43]. The lab measurements for the mud gel strength are performed in a static condition after $10 \mathrm{sec}, 10$ minutes, and 30 minutes to evaluate the strength of the mud gelation with time for no circulation case. Figure 7 represents the gel strength measurements of high WBDFBOB for different $\mathrm{pH}$ values. Increasing the $\mathrm{pH}$ values significantly decreased the gel strength values. Therefore, $\mathrm{pH}$ has a key role in the mud gel strength. The 10-seconds gel strength values decreased from 10 to $3 \mathrm{lb} / 100 \mathrm{ft}^{2}$ by increasing the $\mathrm{pH}$ from 8 to 12 . The WBDFBOB gel strength values for 10-minutes readings showed a decreasing behavior from 30 to $3 \mathrm{lb} / 100 \mathrm{ft}^{2}$. The readings for the 30-minutes gel strength decreased from 57 to $3 \mathrm{lb} / 100 \mathrm{ft}^{2}$. The flat rheology for the mud is desired, as the fluid gel strength values should be constant with time with no increase [44]. The measurements of the WBDFBOB at a pH of 12 showed that flat rheology. However, the readings for the gel strength showed a slightly small increase for the samples of $\mathrm{pH}$ [9-11].

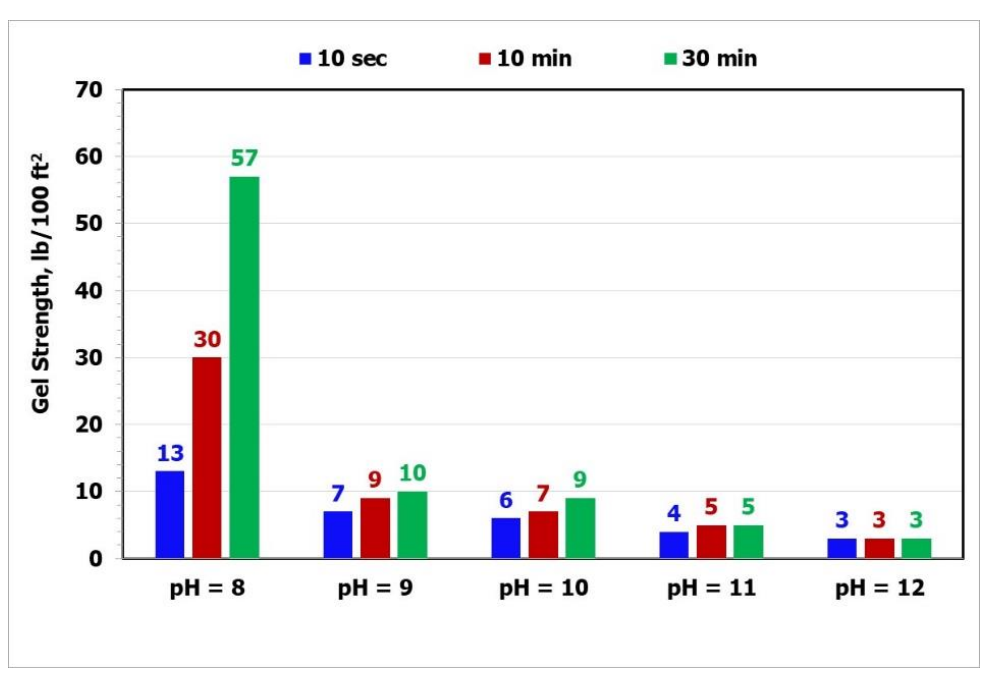

Figure 7. Gel strength measurements of WBDFBOB for different $\mathrm{pH}$. 


\subsection{Filtration Properties}

The HPHT filtration test results are plotted in Figure 8, which shows that the lower the $\mathrm{pH}$ for HBWBDF, the lower the filtrate volume, and vice versa. The bentonite-based mud sample that has $9.0 \mathrm{pH}$ represents the lower filtrate volume $9.5 \mathrm{~cm}^{3}$, and increasing the $\mathrm{pH}$ resulted in increasing the filtrated volume up to $12.6 \mathrm{~cm}^{3}$ for the WBDFBOB sample of $12 \mathrm{pH}$.

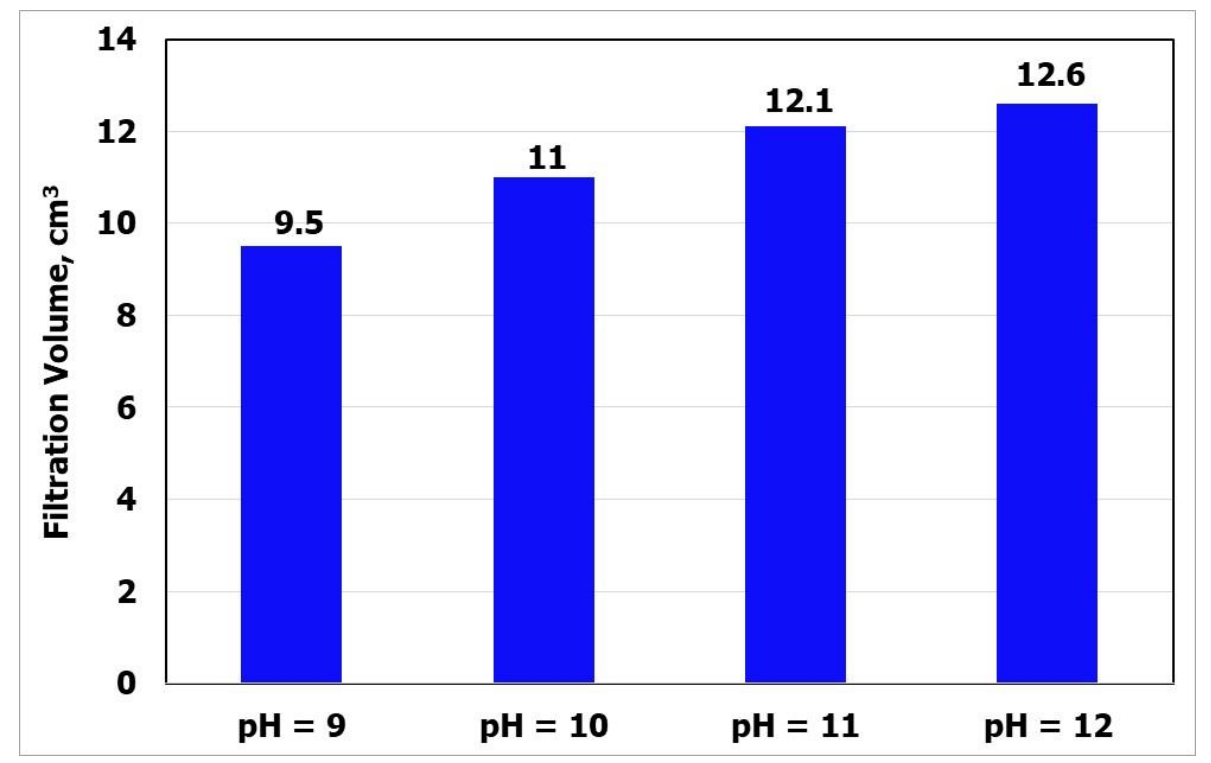

Figure 8. Filtrate volume for different $\mathrm{pH}$ samples of WBDFBOB after 30 minutes.

The filter cake thickness also increased by increasing the $\mathrm{pH}$. Figure 9 shows that for the mud sample with a $\mathrm{pH}$ of 9 , the filter cake thickness was $2 \mathrm{~mm}$. While increasing the $\mathrm{pH}$, it was found that the filter cake thickness increased to $3.6 \mathrm{~mm}$ for WBDFBOB sample of $12 \mathrm{pH}$. Figure 10 shows the pictures for the filter cake formed for each filter press test for different $\mathrm{pH}$ samples of the HBWBDF.

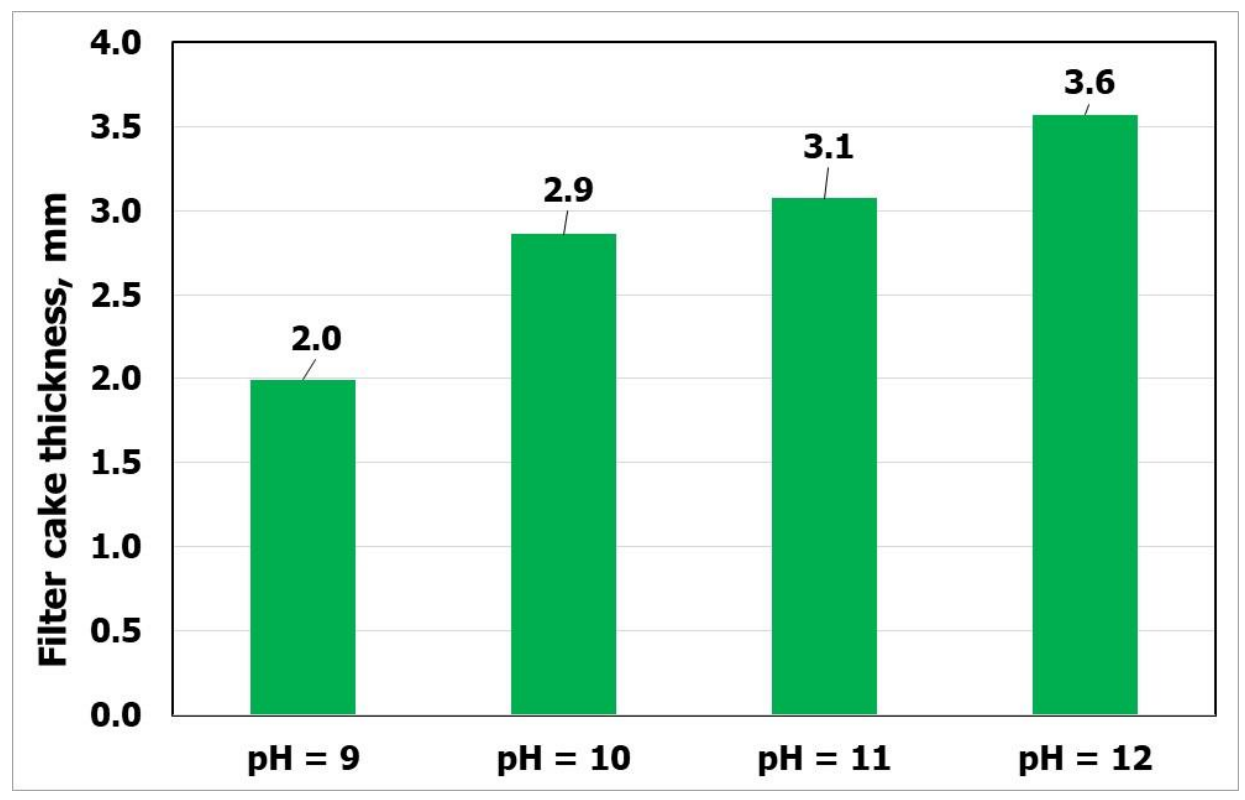

Figure 9. Filter cake thickness for different $\mathrm{pH}$ samples of HBWBDF. 


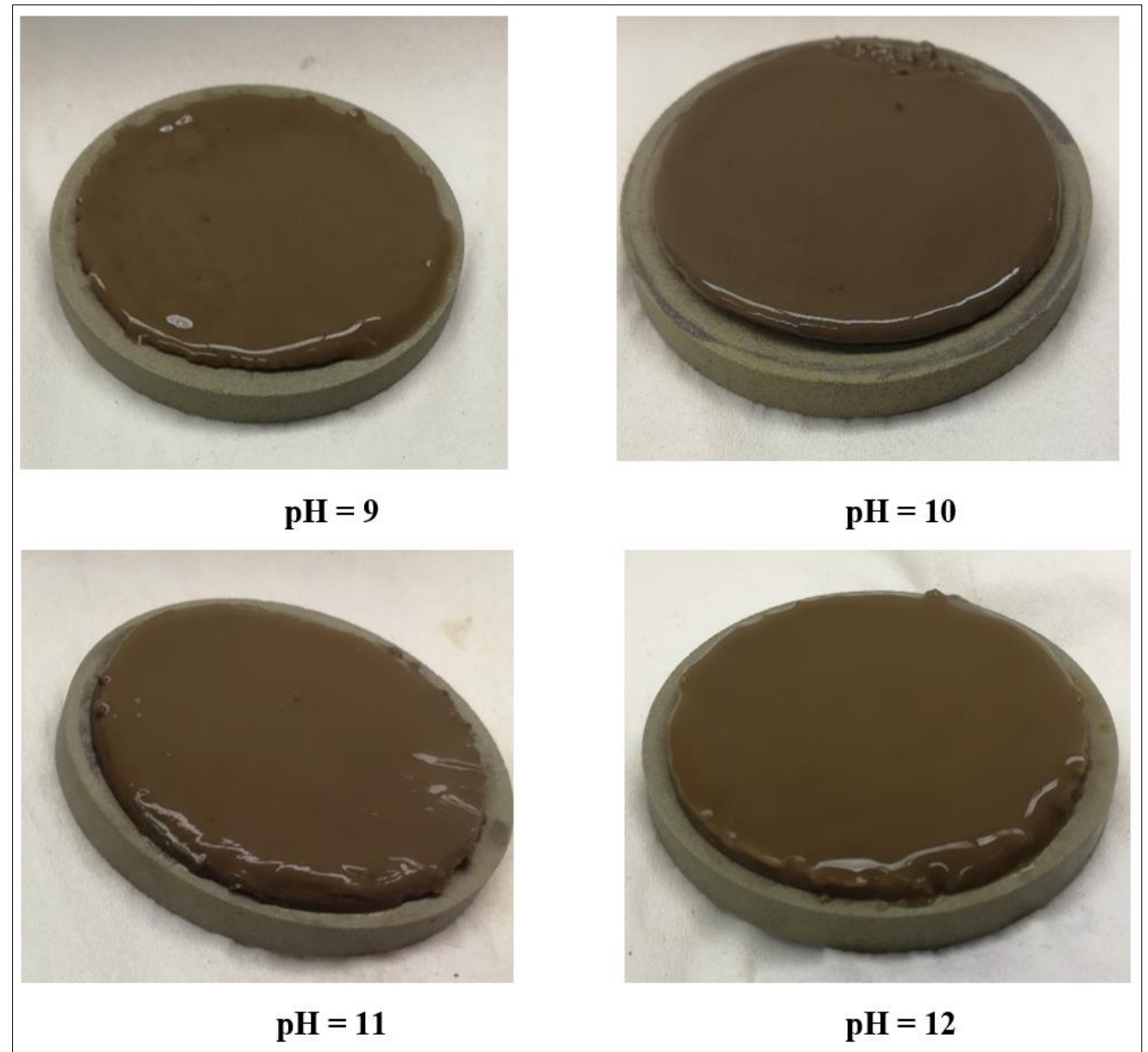

Figure 10. Filter cake for different $\mathrm{pH}$ samples of HBWBDF.

\subsection{Recommendation}

In this study, the use of the WBDFBOB within $\mathrm{pH}$ in the range of 9 and 10 provided the best parameters for filtration and mud rheology comparing to the higher $\mathrm{pH}$ values [11,12], which could help for safe drilling operations. For the recommended $\mathrm{pH}[9,10]$ values, the YP/PV ratio is 1.0, the fluid has a good flat profile where gel strength readings are very close, and the filtration results presented the lowest filtrated volume (from 9.5 to $11 \mathrm{~cm}^{3}$ ) and filter cake thickness (from 2 to $2.9 \mathrm{~mm}$ ).

\section{Summary and Conclusions}

The effect of the $\mathrm{pH}$ change on the water-based drilling fluid based on bentonite was experimentally investigated. Based on the obtained results, the following conclusions can be summarized:

- The $\mathrm{pH}$ significantly affects the mud rheology for the WBDFBOB, and there was no change in the fluid density as it remained constant at $8.8 \mathrm{ppg}$ with changing the $\mathrm{pH}$ from 9 to 12 .

- The shear-stress vs shear-rate curve changed with changing the $\mathrm{pH}$. Increasing the $\mathrm{pH}$ resulted in decreasing the shear-stress over the same shear-rate.

- It is clear that increasing the $\mathrm{pH}$ from 8 to 12 resulted in decreasing the plastic viscosity by $53 \%$ and the YP by $82 \%$, respectively. The highest value of YP/PV was 1.4 for the mud sample with a $\mathrm{pH}$ of 8 . The YP/PV ratios were decreased by $64 \%$ as the $\mathrm{pH}$ increased from 8 to 12 .

- Increasing the $\mathrm{pH}$ from 8 to 12 had a significant effect on the gel strength where the 10 -sec gel strength was decreased by $77 \%$, the 10-min gel strength was decreased by $90 \%$, and the 30 min gel strength was decreased by $95 \%$. 
- Changing the $\mathrm{pH}$ for the bentonite-based samples had an impact on the filtration properties for the mud. Increasing the $\mathrm{pH}$ from 9 to 10 resulted in increasing the filtrated volume by $33 \%$ and also increasing the filter cake thickness by $79 \%$.

It is clear that optimizing the $\mathrm{pH}$ in the range of 9 to 10 has a significant effect on the rheological properties and the mud filtration which will enhance the performance of the drilling operation. Reducing the PV will increase the rate of penetration and will reduce the pump pressure required to circulate the fluid up to the surface. In addition, reducing the filtrate volume will eliminate the formation damage and will yield a thin filter cake which helps in eliminating the pipe sticking, and as a result, reducing the nonproductive time.

Unit Conversion: $1 \mathrm{ppg}=0.0083 \mathrm{~kg} / \mathrm{m}^{3}, 1^{\circ} \mathrm{F}=255.928^{\circ} \mathrm{K}, 1 \mathrm{lb} / \mathrm{ft}^{2}=4.788 \mathrm{E} 5 \mathrm{~N} / \mathrm{mm}^{2}, \mathrm{cP}=10^{-3}$ Pa.s, $1 \mathrm{ft}=0.3028 \mathrm{~m}$.

Author Contributions: Conceptualization, S.B., and H.G.; methodology, S.B., A.A.-M.; validation, S.E., H.G.; formal analysis, S.B., H.G.; investigation, A.A.-M., S.E.; resources, S.E.; data curation, S.B.; writing-original draft preparation, H.G.; writing—review and editing, S.E., A.A.-M.; visualization, A.A.-M., S.E.; supervision, S.E.

Funding: This research received no external funding.

Acknowledgments: The authors wish to acknowledge King Fahd University of Petroleum and Minerals (KFUPM) for utilizing the various facilities in carrying out this research.

Conflicts of Interest: The author declares no conflict of interest.

\section{References}

1. Chilingarian, G.V.; Alp, E.; Al-Salem, M.; Uslu, S.; Gonzales, S.; Dorovi, R.J. Drilling fluid evaluation using yield point-plastic viscosity correlation. Energy Sources 1983, 8, 233-244. [CrossRef]

2. Jenkins, P.B.; Crockford, A.L. Drilling Costs. In Proceedings of the SPE European Spring Meeting, London, UK, 14-15 April 1975. [CrossRef]

3. Okoro, E.E.; Dosunmu, A.; Iyuke, S.E. Data on Cost analysis of drilling mud displacement during drilling operation. Data Brief 2018, 19, 535-541. [CrossRef] [PubMed]

4. Bleier, R. Selecting a drilling fluid. J. Pet. Technol. 1990, 42, 832-834. [CrossRef]

5. Knox, D.; Jiang, P. Drilling further with water-based fluids-selecting the right lubricant. In Proceedings of the SPE International Symposium on Oilfield Chemistry, The Woodlands, TX, USA, 2-4 February 2005. [CrossRef]

6. Li, M.C.; Wu, Q.; Song, K.; De Hoop, C.F.; Lee, S.; Qing, Y.; Wu, Y. Cellulose nanocrystals and polyanionic cellulose as additives in bentonite water-based drilling fluids: Rheological modeling and filtration mechanisms. Ind. Eng. Chem. Res. 2015, 55, 133-143. [CrossRef]

7. Temraz, M.G.; Hassanien, I. Mineralogy and rheological properties of some Egyptian bentonite for drilling fluids. J. Nat. Gas Sci. Eng. 2016, 31, 791-799. [CrossRef]

8. Song, K.; Wu, Q.; Li, M.C.; Wojtanowicz, A.K.; Dong, L.; Zhang, X.; Ren, S.; Lei, T. Performance of low solid bentonite drilling fluids modified by cellulose nanoparticles. J. Nat. Gas Sci. Eng. 2016, 34, 1403-1411. [CrossRef]

9. Song, K.; Wu, Q.; Li, M.; Ren, S.; Dong, L.; Zhang, X.; Lei, T.; Kojima, Y. Water-based bentonite drilling fluids modified by novel biopolymer for minimizing fluid loss and formation damage. Colloids Surf. A Physicochem. Eng. Asp. 2016, 507, 58-66. [CrossRef]

10. Magzoub, M.I. Development of Stable Bentonite for Drilling Fluid Formulations Using Local Sources. Master's Thesis, King Fahd University of Petroleum and Minerals, Dhahran, Saudi Arabia, 2014.

11. Li, M.C.; Wu, Q.; Song, K.; French, A.D.; Mei, C.; Lei, T. pH-responsive water-based drilling fluids containing bentonite and chitin nanocrystals. ACS Sustain. Chem. Eng. 2018, 6, 3783-3795. [CrossRef]

12. Diman, S.F.; Wijeyesekera, D.C. Swelling Characteristics of Bentonite Clay Mats. In Proceedings of the AC\&T 3rd Annual Conference, Royal Docks, 2008; Available online: http://hdl.handle.net/10552/781 (accessed on 10 September 2019).

13. Clem, A.G.; Doehler, R.W. Industrial applications of bentonite. Clays Clay Miner. 1961, 10, 272-283. [CrossRef] 
14. Lebedenko, F.; Plée, D. Some considerations on the ageing of Na2CO3-activated bentonites. Appl. Clay Sci. 1988, 3, 1-10. [CrossRef]

15. Al-Homadhi, E.S. Improving Local Bentonite Performance for Drilling Fluids Applications. In Proceedings of the SPE Saudi Arabia Section Technical Symposium, Dhahran, Saudi Arabia, 7-8 May 2007. [CrossRef]

16. Falode, O.A.; Ehinola, O.A.; Nebeife, P.C. Evaluation of local bentonitic clay as oil well drilling fluids in Nigeria. Appl. Clay Sci. 2008, 39, 19-27. [CrossRef]

17. Mahto, V.; Sharma, V.P. Rheological study of a water based oil well drilling fluid. J. Pet. Sci. Eng. 2004, 45, 123-128. [CrossRef]

18. Kirsner, J.; Siems, D.; Burrows-Lawson, K.; Carbajal, D.; Robb, I.; Jamison, D.E. Methods of Drilling Using Flat Rheology Drilling Fluids. U.S. Patent No. 7,456,135, 25 November 2008.

19. Ahmad, H.M.; Kamal, M.S.; Al-Harthi, M.A. High molecular weight copolymers as rheology modifier and fluid loss additive for water-based drilling fluids. J. Mol. Liq. 2018, 252, 133-143. [CrossRef]

20. Saboori, R.; Sabbaghi, S.; Kalantariasl, A. Improvement of rheological, filtration and thermal conductivity of bentonite drilling fluid using copper oxide/polyacrylamide nanocomposite. Powder Technol. 2019, 353, 257-266. [CrossRef]

21. Vryzas, Z.; Kelessidis, V.C. Nano-based drilling fluids: A review. Energies 2017, 10, 540. [CrossRef]

22. Kosynkin, D.V.; Ceriotti, G.; Wilson, K.C.; Lomeda, J.R.; Scorsone, J.T.; Patel, A.D.; Friedheim, J.E.; Tour, J.M. Graphene oxide as a high-performance fluid-loss-control additive in water-based drilling fluids. ACS Appl. Mater. Interfaces 2011, 4, 222-227. [CrossRef]

23. William, J.K.M.; Ponmani, S.; Samuel, R.; Nagarajan, R.; Sangwai, J.S. Effect of CuO and ZnO nanofluids in xanthan gum on thermal, electrical and high pressure rheology of water-based drilling fluids. J. Pet. Sci. Eng. 2014, 117, 15-27. [CrossRef]

24. Yan, L.; Wang, C.; Xu, B.; Sun, J.; Yue, W.; Yang, Z. Preparation of a novel amphiphilic comb-like terpolymer as viscosifying additive in low-solid drilling fluid. Mater. Lett. 2013, 105, 232-235. [CrossRef]

25. Liu, F.; Jiang, G.; Peng, S.; He, Y.; Wang, J. Amphoteric polymer as an anti-calcium contamination fluid-loss additive in water-based drilling fluids. Energy Fuels 2016, 30, 7221-7228. [CrossRef]

26. Xie, B.; Liu, X. Thermo-thickening behavior of LCST-based copolymer viscosifier for water-based drilling fluids. J. Pet. Sci. Eng. 2017, 154, 244-251. [CrossRef]

27. Jung, Y.; Son, Y.H.; Lee, J.K.; Phuoc, T.X.; Soong, Y.; Chyu, M.K. Rheological behavior of clay-nanoparticle hybrid-added bentonite suspensions: Specific role of hybrid additives on the gelation of clay-based fluids. ACS Appl. Mater. Interfaces 2011, 3, 3515-3522. [CrossRef] [PubMed]

28. Barry, M.M.; Jung, Y.; Lee, J.K.; Phuoc, T.X.; Chyu, M.K. Fluid filtration and rheological properties of nanoparticle additive and intercalated clay hybrid bentonite drilling fluids. J. Pet. Sci. Eng. 2015, 127, 338-346. [CrossRef]

29. Mao, H.; Qiu, Z.; Shen, Z.; Huang, W. Hydrophobic associated polymer based silica nanoparticles composite with core-shell structure as a filtrate reducer for drilling fluid at utra-high temperature. J. Pet. Sci. Eng. 2015, 129, 1-14. [CrossRef]

30. Ponmani, S.; Nagarajan, R.; Sangwai, J.S. Effect of nanofluids of $\mathrm{CuO}$ and $\mathrm{ZnO}$ in polyethylene glycol and polyvinylpyrrolidone on the thermal, electrical, and filtration-loss properties of water-based drilling fluids. SPE J. 2016, 21, 405-415. [CrossRef]

31. Li, M.C.; Wu, Q.; Song, K.; De Hoop, C.F.; Lee, S.; Qing, Y.; Wu, Y. Cellulose nanoparticles as modifiers for rheology and fluid loss in bentonite water-based fluids. ACS Appl. Mater. Interfaces 2015, 7, 5006-5016. [CrossRef] [PubMed]

32. Abdo, J.; Zaier, R.; Hassan, E.; Al-Sharji, H.; Al-Shabibi, A. ZnO-clay nanocomposites for enhance drilling at HTHP conditions. Surf. Interface Anal. 2014, 46, 970-974. [CrossRef]

33. Kanna, A.P.; Savi, S.; Khan, M. Determination of effect bentonite and additives on drilling fluids. Int. Refereed J. Eng. Sci. (IRJES) 2017, 6, 22-28.

34. Huang, W.; Leong, Y.K.; Chen, T.; Au, P.I.; Liu, X.; Qiu, Z. Surface chemistry and rheological properties of API bentonite drilling fluid: $\mathrm{pH}$ effect, yield stress, zeta potential and ageing behaviour. J. Pet. Sci. Eng. 2016, 146, 561-569. [CrossRef]

35. Akinade, A.E.; Wilfred, O.C.; Akin-Taylor, A.M. Improving the rheological properties of drilling mud using local based materials. Am. J. Eng. Res. (AJER) 2018, 7, 58-63. 
36. Kuma, M.; Das, B.M.; Talukdar, P. The effect of salts and haematite on carboxymethyl cellulose-Bentonite and partially hydrolyzed polyacrylamide-Bentonite muds for an effective drilling in shale formations. J. Pet. Explor. Prod. Technol. 2019. [CrossRef]

37. Saboorian-Jooybari, H.; Dejam, M.; Chen, Z. Heavy oil polymer flooding from laboratory core floods to pilot tests and field applications: Half-century studies. J. Pet. Sci. Eng. 2016, 142, 85-100. [CrossRef]

38. Mashayekhizadeh, V.; Kord, S.; Dejam, M. EOR potential within Iran. Spec. Top. Rev. Porous Media Int. J. 2014, 5, 325-354. [CrossRef]

39. Amirian, E.; Dejam, M.; Chen, Z. Performance forecasting for polymer flooding in heavy oil reservoirs. Fuel 2018, 216, 83-100. [CrossRef]

40. Beck, F.E.; Powell, J.W.; Zamora, M. The Effect of Rheology on Rate of Penetration. In Proceedings of the SPE/IADC Drilling Conference, Amsterdam, The Netherlands, 28 February-2 March 1995. [CrossRef]

41. Rabaioli, M.R.; Miano, F.; Lockhart, T.P.; Burrafato, G. Physical/Chemical Studies on the Surface Interactions of Bentonite with Polymeric Dispersing Agents. Society of Petroleum Engineers. In Proceedings of the SPE International Symposium on Oilfield Chemistry, New Orleans, LA, USA, 2-5 March 1993. [CrossRef]

42. Zamora, M.; Power, D. Making a Case for AADE Hydraulics and the Unified Rheological Model; Paper AADE-02-DFWM-HO-13. In Proceedings of the AADE 2002 Technology Conference "Drilling \& Completion Fluids and Waste Management", Radisson Astrodome, Houston, TX, USA, 2-3 April 2002.

43. Elkatatny, S. Assessing the Effect of Micronized Starch on Rheological and Filtration Properties of Water-Based Drilling Fluid. In Proceedings of the SPE Middle East Oil and Gas Show and Conference, Manama, Bahrain, 18-21 March 2019. [CrossRef]

44. Amani, M.; Hassiba, K.J. Salinity Effect on the Rheological Properties of Water Based Mud under High Pressures and High Temperatures of Deep Wells. In Proceedings of the SPE Kuwait International Petroleum Conference and Exhibition, Kuwait City, Kuwait, 10-12 December 2012. [CrossRef]

(C) 2019 by the authors. Licensee MDPI, Basel, Switzerland. This article is an open access article distributed under the terms and conditions of the Creative Commons Attribution (CC BY) license (http://creativecommons.org/licenses/by/4.0/). 